\title{
PHYLOGENY AND CIRCUMSCRIPTION OF THE GENUS Orinus (Poaceae: Eragrostideae): EVIDENCE FROM NRDNA ITS SEQUENCES
}

\author{
FILOGENIA ITS E A CIRCUNSCRIÇÃO DO GÊNERO Orinus (Poaceae: \\ Eragrostideae): EVIDÊNCIA DAS SEQUÊNCIAS ITS DO NRDNA
}

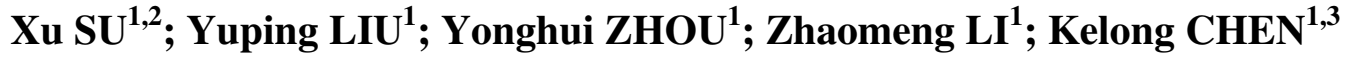

1. Key Laboratory of Medicinal Animal and Plant Resource in the Qinghai-Tibetan Plateau, Key Laboratory of Physical Geography and Environmental Process in Qinghai Province, Key Laboratory of Medicinal Animal and Plant Resource in the Qinghai-Tibetan Plateau of Qinghai Province, Key Laboratory of Education Ministry of Environments and Resources in the Qinghai-Tibetan Plateau, School of Geography and Life Science, Qinghai Normal University, Xining City of Qinghai Province, China; 2. State Key Laboratory Breeding Base-Key Laboratory of Qinghai Province for Plateau Crop Germplasm Innovation and Utilization, Qinghai University, Xining City of Qinghai Province, China; 3. Science and Technology Department, Qinghai Normal University, Xining City of Qinghai Province, China. xusu8527972@126.com
\end{abstract}

\begin{abstract}
In this study, ITS sequences of the nuclear ribosomal DNA were conducted for six putative species of Orinus (O. alticulmus, O. anomala, O. kokonorica, O. longiglumis, O. thoroldii and O. tibeticus) with 572 individuals from 73 populations. The results found that the six species formed two monophyletic groups: the one $(O$. anomala Keng ex Keng f. and L. Liou) with $O$. alticulmus, O. anomala and $O$. kokonorica, and another (O. thoroldii (Stapfex Hemsl.) Bor) with $O$. longiglumis, O. thoroldii and O. tibeticus. The taxonomic data from ITS sequences were not congruent with those from morphological characteristics, likely resulting from rapid speciation trigged by the uplifts of the Qinghai-Tibetan Plateau and its adjacent regions and the extensive selection pressure under the alpine environments. The ITS data suggest that the classification of the six species within the genus Orinus should be reduced to two species. We include a complete taxonomic revision of the genus and a key to distinguish the two species. Therefore, it is very necessary to make the comprehensive revision and arrangement of these taxa, strictly regulate the taxa confusion of genus and species order, and do new reports on belonging to the genus taxa.
\end{abstract}

KEYWORDS: Qinghai-Tibetan Plateau. Orinus. Circumscription. Phylogeny. ITS.

\section{INTRODUCTION}

Orinus Hitchc., an alpine perennial grass genus, belongs to Tridentinae of Eragrostideae (Poaceae) (KENG et al. 1960) and was established by Hitchcock (1933) based on the species $O$. arenicola Hitchc., which was collected for the first time in Kashmir region. In 1950s, another species of Orinus, O. anomala Keng ex Keng f. and L. Liou, was discovered by Keng $(1957,1959)$ and validated by Keng and Liou (1960). And almost simultaneously, Bor (1960) further confirmed $O$. arenicola Hitchc. was Diplachne thoroldii Stapf ex Hemsley, which was previously described from Tibet region (STAPF, 1894). Thus, the type species of Orinus had to be shifted to O. thoroldii (Stapf ex Hemsl.) Bor by Bor (1952) according to the international rules of nomenclature, and subsequently, Tzvelev (1968) classified Cleistogenes kokonorica K. S. Hao as O. kokonorica (K. S. Hao) Tzvelev. Meanwhile, Zhao and Li (1994) described a new species, O. tibeticus N. X. Zhao, from Tibet. Recently, Zhang and Cai (2008) and Su and Cai (2009) individually reported a new species, O. alticulmus L. B. Cai and T. L. Zhang and $O$. longiglumis L. B. Cai and X. Su, on journals Novon and Annales Botanici Fennici, respectively.
Totally, six species are accepted to date in genus Orinus. These six species are mainly distributed on the Qinghai-Tibetan Plateau and its adjacent regions from 2230-5200 $\mathrm{m}$ above sea level.

The genus Orinus has important economic and ecological values on the Qinghai-Tibetan Plateau, P. R. China. Their germplasms are often used to improve cereal crops to deal with drought, cold, alkali and disease conditions. However, there are many unresolved taxonomic questions in Orinus, such as species delimitation and interspecific phylogenetic relationships, due to the large morphological variance and a variety of transitional characters among species. Species delimitation is a precondition for determining the phylogeny and intergeneric relationships of a genus (RIESERBERG et al. 2006). Obtaining phenetic groups from many morphological characters with a variety of methods (i.e. principal component analysis, PCA) is the basis of inter-species delimitation (RIESERBERG et al. 2006). Recently, DNA barcoding has become one of the most effective marking methods to examine phenetic groups (LI et al. 2011a, b). The ITS sequences are more important than chloroplast DNA fragments as $r b c \mathrm{~L}, m a t \mathrm{~K}, t r n \mathrm{H}-p s b \mathrm{~A}$ formerly used and has been widely used in reconstructing the phylogeny and 
taxonomic questions of interspecific species, related genus and even division in angiosperms (BALDWIN, 1992, 1993; BALDWIN et a1. 1995; GAO et al. 2003; LIU, 2006; SOLTIS, 1998; TIAN et al. 2002; VARGAS et a1. 1998; WANG et al. 2004; WANG, 2005). Our objectives intend to answer the following questions: (1) how many species should be recognized or delimited for this genus; and (2) what are phylogenetic relationships between these species?

\section{MATERIAL AND METHODS}

\section{Population sampling}

A total of 572 individuals were sampled from 73 populations of Orinus, covering most of the geographical ranges of the six previously recognized species on the Qinghai-Tibetan Plateau and its adjacent regions (Table 1 and Figure 1). Sample sizes for each population ranged from 5 to 15 individuals and these were usually separated from each other by more than $10 \mathrm{~m}$. Leaves collected for DNA extraction were rapidly dried and preserved in silica gel at room temperature. Voucher specimens of all populations were deposited in the HNWP, P. R China.

Table 1. Locations of each Orinus species and the individuals analyzed for ITS research

\begin{tabular}{|c|c|c|c|c|c|c|}
\hline $\begin{array}{l}\text { Previously } \\
\text { recognized species }\end{array}$ & Locality & Longitude (N) & Latitude (E) & Altitude (m) & $\begin{array}{l}\text { Voucher } \\
\text { specimens }\end{array}$ & $\begin{array}{l}\text { Currently } \\
\text { revised } \\
\text { species }\end{array}$ \\
\hline \multirow[t]{5}{*}{ O. alticulmus } & Xining, QH & $36^{\circ} 36^{\prime} 42.8^{\prime \prime}$ & $101^{\circ} 48^{\prime} 7.8^{\prime \prime}$ & 2450 & X. Su, 11301 & O. anomala \\
\hline & Gonghe, QH & $36^{\circ} 11^{\prime} 3.0^{\prime \prime}$ & $100^{\circ} 59^{\prime} 16.9^{\prime \prime}$ & 2826 & X. Su, 12040 & \\
\hline & Xining, QH & $36^{\circ} 37^{\prime} 13.0^{\prime \prime}$ & $101^{\circ} 44^{\prime} 29.8^{\prime \prime}$ & 2468 & X. Su, 12041 & \\
\hline & Xining, QH & $36^{\circ} 35^{\prime} 19.2^{\prime \prime}$ & $101^{\circ} 42^{\prime} 20.5^{\prime \prime}$ & 2568 & X. Su, 11042 & \\
\hline & Xining, QH & $36^{\circ} 37^{\prime} 10.8^{\prime \prime}$ & $101^{\circ} 44^{\prime} 1.7^{\prime \prime}$ & 2547 & X. Su, 12042 & \\
\hline \multirow[t]{14}{*}{ O. kokonorica } & Haiyan, QH & $36^{\circ} 50^{\prime} 8.3^{\prime \prime}$ & $100^{\circ} 50^{\prime} 6.1^{\prime \prime}$ & 3305 & X. Su, 11005 & \\
\hline & Gonghe, QH & $36^{\circ} 13^{\prime} 1.3^{\prime \prime}$ & $100^{\circ} 32^{\prime} 25.3^{\prime \prime}$ & 2918 & X. Su, 11014 & \\
\hline & Nangqian, QH & $32^{\circ} 32^{\prime} 50.6^{\prime \prime}$ & $96^{\circ} 11^{\prime} 45.2^{\prime \prime}$ & 4119 & X. Su, 11075 & \\
\hline & Nangqian, QH & $32^{\circ} 29^{\prime} 24.4^{\prime \prime}$ & $96^{\circ} 16^{\prime} 7.5^{\prime \prime}$ & 3728 & X. Su, 11082 & \\
\hline & Xinghai, QH & $35^{\circ} 53^{\prime} 35.0^{\prime \prime}$ & $99^{\circ} 59^{\prime} 32.0^{\prime \prime}$ & 3500 & X. Su, 20429 & \\
\hline & Xinghai, QH & $35^{\circ} 53^{\prime} 35.0^{\prime \prime}$ & $99^{\circ} 59^{\prime} 32.0^{\prime \prime}$ & 3600 & X. Su, 00483 & \\
\hline & Qilian, QH & $37^{\circ} 54^{\prime} 00.0^{\prime \prime}$ & $100^{\circ} 20^{\prime} 40.0^{\prime \prime}$ & 3400 & X. Su, 12561 & \\
\hline & Gonghe, QH & $36^{\circ} 54^{\prime} 36.0^{\prime \prime}$ & $100^{\circ} 10^{\prime} 48.0^{\prime \prime}$ & 3280 & X. Su, 40338 & \\
\hline & Yushu, QH & $34^{\circ} 12^{\prime} 00.0^{\prime \prime}$ & $97^{\circ} 36^{\prime} 00.0^{\prime \prime}$ & 4600 & X. Su, 41338 & \\
\hline & Yushu, QH & $33^{\circ} 1^{\prime} 48.0^{\prime \prime}$ & $96^{\circ} 58^{\prime} 12.0^{\prime \prime}$ & 3400 & X. Su, 22386 & \\
\hline & Gonghe, $\mathrm{QH}$ & $36^{\circ} 21^{\prime} 26.3^{\prime \prime}$ & $100^{\circ} 43^{\prime} 5.8^{\prime \prime}$ & 3130 & X. Su, 13008 & \\
\hline & Gonghe, QH & $36^{\circ} 12^{\prime} 50.6^{\prime \prime}$ & $100^{\circ} 32^{\prime} 20.3^{\prime \prime}$ & 2924 & X. Su, 13009 & \\
\hline & Xinghai, QH & $35^{\circ} 36^{\prime} 43.1^{\prime \prime}$ & $99^{\circ} 57^{\prime} 13.6^{\prime \prime}$ & 3337 & X. Su, 13016 & \\
\hline & Yushu, QH & $32^{\circ} 58^{\prime} 55.6^{\prime \prime}$ & $97^{\circ} 14^{\prime} 17.6^{\prime \prime}$ & 3493 & X. Su, 13095 & \\
\hline \multirow[t]{13}{*}{ O. anomala } & Gonghe, QH & $36^{\circ} 6.0^{\prime} 0.5^{\prime \prime}$ & $100^{\circ} 24^{\prime} 16.0^{\prime \prime}$ & 2988 & X. Su, 11016 & \\
\hline & Nangqian, QH & $32^{\circ} 32^{\prime} 50.6^{\prime \prime}$ & $96^{\circ} 11^{\prime} 45.2^{\prime \prime}$ & 4119 & X. Su, 11074 & \\
\hline & Dingqing, $X Z$ & $31^{\circ} 15^{\prime} 57.4^{\prime \prime}$ & $95^{\circ} 49^{\prime} 57.0^{\prime \prime}$ & 3603 & X. Su, 11152 & \\
\hline & Xiahe, GS & $35^{\circ} 11^{\prime} 0.92^{\prime \prime}$ & $102^{\circ} 30^{\prime} 59.7^{\prime \prime}$ & 3007 & X. Su, 11295 & \\
\hline & Dingqing, $\mathrm{XZ}$ & $31^{\circ} 13^{\prime} 20.0^{\prime \prime}$ & $95^{\circ} 58^{\prime} 14.8^{\prime \prime}$ & 3692 & X. Su, 12023 & \\
\hline & Changdu, XZ & $31^{\circ} 29^{\prime} 36.7^{\prime \prime}$ & $97^{\circ} 12^{\prime} 21.1^{\prime \prime}$ & 3354 & X. Su, 12027 & \\
\hline & Jiangda, XZ & $31^{\circ} 20^{\prime} 20.8^{\prime \prime}$ & $98^{\circ} 8^{\prime} 2.2^{\prime \prime}$ & 3818 & X. Su, 12032 & \\
\hline & Gonghe, QH & $36^{\circ} 2^{\prime} 21.8^{\prime \prime}$ & $100^{\circ} 18^{\prime} 55.6^{\prime \prime}$ & 3072 & X. Su, 12038 & \\
\hline & Huangyuan, QH & $36^{\circ} 46^{\prime} 55.1^{\prime \prime}$ & $101^{\circ} 7^{\prime} 16.3^{\prime \prime}$ & 2831 & X. Su, 13001 & \\
\hline & Gonghe, QH & $36^{\circ} 42^{\prime} 13.7^{\prime \prime}$ & $100^{\circ} 47^{\prime} 30.0^{\prime \prime}$ & 3232 & X. Su, 13003 & \\
\hline & Dingqing, $X Z$ & $31^{\circ} 36^{\prime} 18.9^{\prime \prime}$ & $95^{\circ} 6^{\prime} 53.8^{\prime \prime}$ & 3786 & X. Su, 13087 & \\
\hline & Dingqing, $X Z$ & $31^{\circ} 16^{\prime} 22.6^{\prime \prime}$ & $95^{\circ} 49^{\prime} 42.7^{\prime \prime}$ & 3594 & X. Su, 13088 & \\
\hline & Leiwuqi, XZ & $31^{\circ} 45^{\prime} 12.8^{\prime \prime}$ & $96^{\circ} 19^{\prime} 51.2^{\prime \prime}$ & 3624 & X. Su, 13090 & \\
\hline \multirow[t]{5}{*}{ O. thoroldii } & Rikaze, XZ & $29^{\circ} 18^{\prime} 0.4^{\prime \prime}$ & $89^{\circ} 46^{\prime} 7.3^{\prime \prime}$ & 3767 & X. Su, 11018 & O. thoroldii \\
\hline & Rikaze, XZ & $29^{\circ} 20^{\prime} 20.9^{\prime \prime}$ & $89^{\circ} 15^{\prime} 41.0^{\prime \prime}$ & 3796 & X. Su, 11020 & \\
\hline & Lazi, XZ & $29^{\circ} 9^{\prime} 28.3^{\prime \prime}$ & $88^{\circ} 10^{\prime} 16.9^{\prime \prime}$ & 4060 & X. Su, 11033 & \\
\hline & Angren, XZ & $29^{\circ} 26^{\prime} 24.0^{\prime \prime}$ & $86^{\circ} 39^{\prime} 52.6^{\prime \prime}$ & 4593 & X. Su, 11034 & \\
\hline & Shaga, XZ & $29^{\circ} 23^{\prime} 31.5^{\prime \prime}$ & $85^{\circ} 30^{\prime} 57.4^{\prime \prime}$ & 4677 & X. Su, 11039 & \\
\hline
\end{tabular}




\begin{tabular}{|c|c|c|c|c|c|}
\hline & Shaga, XZ & $29^{\circ} 30^{\prime} 1.4^{\prime \prime}$ & $84^{\circ} 33^{\prime} 39.6^{\prime \prime}$ & 4578 & X. Su, 11043 \\
\hline & Zhongba, XZ & $29^{\circ} 41^{\prime} 7.9^{\prime \prime}$ & $84^{\circ} 8^{\prime} 48.1^{\prime \prime}$ & 4563 & X. Su, 11044 \\
\hline & Zhongba, XZ & $29^{\circ} 59^{\prime} 45.6^{\prime \prime}$ & $83^{\circ} 31^{\prime} 43.1^{\prime \prime}$ & 4582 & X. Su, 11045 \\
\hline & Pulan, XZ & $30^{\circ} 48^{\prime} 35.8^{\prime \prime}$ & $81^{\circ} 34^{\prime} 22.5^{\prime \prime}$ & 4610 & X. Su, 11049 \\
\hline & Pulan, XZ & $31^{\circ} 10^{\prime} 42.6^{\prime \prime}$ & $80^{\circ} 45^{\prime} 26.8^{\prime \prime}$ & 4427 & X. Su, 11054 \\
\hline & Ge'er, XZ & $31^{\circ} 36^{\prime} 13.7^{\prime \prime}$ & $80^{\circ} 22^{\prime} 15.6^{\prime \prime}$ & 4570 & X. Su, 11055 \\
\hline & Ali, XZ & $32^{\circ} 34^{\prime} 17.9^{\prime \prime}$ & $80^{\circ} 3^{\prime} 10.7^{\prime \prime}$ & 4451 & X. Su, 11056 \\
\hline & Zhada, XZ & $31^{\circ} 40^{\prime} 4.7^{\prime \prime}$ & $79^{\circ} 44^{\prime} 45.7^{\prime \prime}$ & 4011 & X. Su, 11059 \\
\hline & Zhada, XZ & $31^{\circ} 28^{\prime} 46^{\prime \prime}$ & $79^{\circ} 48^{\prime} 9.0^{\prime \prime}$ & 4434 & X. Su, 11070 \\
\hline & Shaga, XZ & $29^{\circ} 0^{\prime} 27.0^{\prime \prime}$ & $85^{\circ} 26^{\prime} 48.8^{\prime \prime}$ & 4687 & X. Su, 11078 \\
\hline & Jilong, XZ & $28^{\circ} 46^{\prime} 6.3^{\prime \prime}$ & $85^{\circ} 32^{\prime} 14.3^{\prime \prime}$ & 4614 & X. Su, 11100 \\
\hline & Dingri, XZ & $28^{\circ} 39^{\prime} 34.2^{\prime \prime}$ & $87^{\circ} 7^{\prime} 45.6^{\prime \prime}$ & 3852 & X. Su, 11119 \\
\hline & Dangxiong, XZ & $30^{\circ} 36^{\prime} 38.8^{\prime \prime}$ & $91^{\circ} 32^{\prime} 11.9^{\prime \prime}$ & 4542 & X. Su, 11185 \\
\hline & Lasha, XZ & $29^{\circ} 37^{\prime} 22.7^{\prime \prime}$ & $91^{\circ} 4^{\prime} 42.8^{\prime \prime}$ & 3661 & X. Su, 11189 \\
\hline & Gongga, XZ & $29^{\circ} 16^{\prime} 56.9^{\prime \prime}$ & $91^{\circ} 0^{\prime} 45.7^{\prime \prime}$ & 3648 & X. Su, 11192 \\
\hline & Zhanang, XZ & $29^{\circ} 12^{\prime} 42.3^{\prime \prime}$ & $91^{\circ} 27^{\prime} 46.1^{\prime \prime}$ & 3560 & X. Su, 11196 \\
\hline & $\begin{array}{l}\text { Lang county, } \\
\text { XZ }\end{array}$ & $29^{\circ} 0^{\prime} 36.9^{\prime \prime}$ & $93^{\circ} 18^{\prime} 55.6^{\prime \prime}$ & 3051 & X. Su, 11202 \\
\hline & Changdu, XZ & $31^{\circ} 15^{\prime} 20.0^{\prime \prime}$ & $97^{\circ} 9^{\prime} 42.4^{\prime \prime}$ & 3298 & X. Su, 12025 \\
\hline & Luolong, XZ & $30^{\circ} 46^{\prime} 38.4^{\prime \prime}$ & $96^{\circ} 8^{\prime} 23.6^{\prime \prime}$ & 3862 & X. Su, 13080 \\
\hline & Luolong, XZ & $30^{\circ} 46^{\prime} 1.2^{\prime \prime}$ & $95^{\circ} 34^{\prime} 27.7^{\prime \prime}$ & 3762 & X. Su, 13081 \\
\hline & Bianba, XZ & $30^{\circ} 49^{\prime} 19.1^{\prime \prime}$ & $94^{\circ} 51^{\prime} 30.7^{\prime \prime}$ & 3999 & X. Su, 13082 \\
\hline & Bianba, XZ & $30^{\circ} 58^{\prime} 40.3^{\prime \prime}$ & $94^{\circ} 43^{\prime} 35.3^{\prime \prime}$ & 3597 & X. Su, 13083 \\
\hline & Bianba, XZ & $31^{\circ} 13^{\prime} 46.8^{\prime \prime}$ & $94^{\circ} 18^{\prime} 12.4^{\prime \prime}$ & 3774 & X. Su, 13084 \\
\hline & Biru, XZ & $31^{\circ} 31^{\prime} 7.8^{\prime \prime}$ & $93^{\circ} 31^{\prime} 59.7^{\prime \prime}$ & 3991 & X. Su, 13085 \\
\hline & Daofu, SC & $30^{\circ} 37^{\prime} 17.7^{\prime \prime}$ & $101^{\circ} 24^{\prime} 15.5^{\prime \prime}$ & 3573 & X. Su, 12008 \\
\hline & Luhuo, SC & $31^{\circ} 38^{\prime} 35.0^{\prime \prime}$ & $100^{\circ} 17^{\prime} 15.9^{\prime \prime}$ & 3534 & X. Su, 13058 \\
\hline & Banma, QH & $33^{\circ} 1^{\prime} 28.9^{\prime \prime}$ & $100^{\circ} 41^{\prime} 52.3^{\prime \prime}$ & 3852 & X. Su, 13032 \\
\hline & Banma, QH & $32^{\circ} 58^{\prime} 15.2^{\prime \prime}$ & $100^{\circ} 43^{\prime} 23.4^{\prime \prime}$ & 3576 & X. Su, 13033 \\
\hline & Banma, QH & $33^{\circ} 3^{\prime} 13.5^{\prime \prime}$ & $100^{\circ} 42^{\prime} 29.7^{\prime \prime}$ & 3578 & X. Su, 13034 \\
\hline \multirow[t]{5}{*}{ O. tibeticus } & Qushui, XZ & $29^{\circ} 29^{\prime} 46.0^{\prime \prime}$ & $90^{\circ} 56^{\prime} 14.6^{\prime \prime}$ & 3617 & X. Su, 11010 \\
\hline & Dingjie, XZ & $28^{\circ} 21^{\prime} 51.0^{\prime \prime}$ & $87^{\circ} 45^{\prime} 57.0^{\prime \prime}$ & 4324 & X. Su, 11120 \\
\hline & Dingri, XZ & $28^{\circ} 39^{\prime} 34.2^{\prime \prime}$ & $87^{\circ} 07^{\prime} 45.6^{\prime \prime}$ & 3852 & X. Su, 11123 \\
\hline & Kangma, XZ & $28^{\circ} 33^{\prime} 20.0^{\prime \prime}$ & $89^{\circ} 41^{\prime} 2.0^{\prime \prime}$ & 4412 & X. Su, 11132 \\
\hline & Zhanang, XZ & $29^{\circ} 15^{\prime} 23.9^{\prime \prime}$ & $91^{\circ} 22^{\prime} 7.1^{\prime \prime}$ & 3586 & X. Su, 11195 \\
\hline \multirow[t]{2}{*}{ O. longiglumis } & Pulan, XZ & $30^{\circ} 21^{\prime} 58.5^{\prime \prime}$ & $81^{\circ} 9^{\prime} 8.3^{\prime \prime}$ & 4260 & X. Su, 11050 \\
\hline & Naidong, XZ & $29^{\circ} 15^{\prime} 36.4^{\prime \prime}$ & $91^{\circ} 43^{\prime} 52.0^{\prime \prime}$ & 3500 & X. Su, 11300 \\
\hline
\end{tabular}

QH, Qinghai; SC, Sichuan; GS, Gansu; XZ, Xizang 


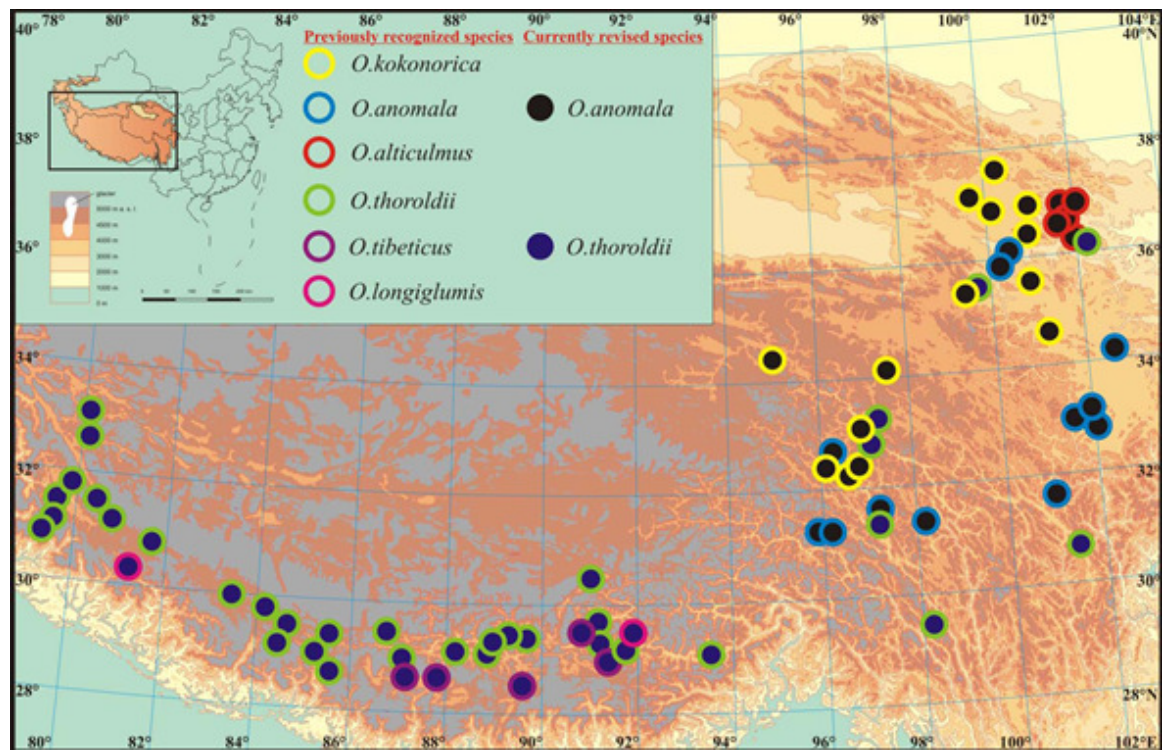

Figure 1. Sampling localities of Orinus surveyed on the Qinghai-Tibetan Plateau.

\section{DNA extraction, PCR amplification and sequencing}

Total genomic DNA was extracted from silica gel dried leaves using the $2 \times$ cetyltrimethylammonium bromide (CTAB) extraction protocol (DOYLE et al. 1987). The external primers pair ITS1/ITS4 (WHITE et al. 1990) was used for the amplification and sequencing of the ITS region. Following the methods of Zhang et al. (2005), the polymerase chain reaction (PCR) amplification for this region was performed in a volume of $25 \mu \mathrm{L}$, containing 2.5 $\mu \mathrm{L}$ of $10 \times$ PCR buffer, $0.2 \mu \mathrm{L}$ Taq DNA polymerase (5 U/ $\mu \mathrm{L}$; TakaRa Biotech, Dalian, China), $0.5 \mathrm{mmol} / \mathrm{L}$ dNTPs, $1.5 \mathrm{mmol} / \mathrm{L} \mathrm{MgCl}_{2}, 2.0$ $\mu \mathrm{mol} / \mathrm{L}$ each primer, and $1.0 \mu \mathrm{L}$ unquantified genomic DNA extract. The PCR reaction profile consisted of one cycle at $94^{\circ} \mathrm{C}$ for $5 \mathrm{~min}$, followed by 36 cycles of $94^{\circ} \mathrm{C}$ for $50 \mathrm{~s}, 57-58^{\circ} \mathrm{C}$ for $50 \mathrm{~s}$, and $72^{\circ} \mathrm{C}$ for $1 \mathrm{~min}$ and $10 \mathrm{~s}$, with a final extension for $10 \mathrm{~min}$ at $72^{\circ} \mathrm{C}$. Samples were then stored at $4^{\circ} \mathrm{C}$ until further processing. The PCR products were purified using a TIAN-quick Midi Purification Kit (Tiangen Biotech, Beijing, China) according to the manufacturer's instructions. The primers used for sequencing the ITS region were the same as described above (ITS1/ITS4). Sequencing reactions were performed on an ABI 3130 sequencer using an ABI Prism Bigdye Terminator Cycle Sequencing Ready Reaction Kit (Applied Biosystems, Foster City, CA, USA). Both DNA strands were sequenced using forward and reverse primers. Sequences were recorded in both strands with an overlap of at least 90\%. The ITS sequences of Leptochloa viscida (Scribn.) Beal and Eragrostis parviflora (R. Br.) Trin. were used as outgroups, retrieved from
GenBank (accession number: GU359148.1 and GU359331.1).

\section{Data analyses}

All sequences of ITS fragments were aligned using the default parameters in Clustal_X (THOMPSON et al. 1997) and refined manually in MEGA 5 (TAMURA et al. 2011). The ITS dataset was subjected to maximum parsimony (MP) using PAUP*4.0b10 (SWOFFORD, 2000) and Bayesian analyses using MrBayes 3.1 (HUELSENBECK et al. 2001). Bayesian analyses were performed using General - time - reversible + gamma $(\mathrm{GTR}+\mathrm{G})$ model in accordance to the result of Modeltest 3.7 (POSADA et al. 1998) and MrModel test 2.2 (POSADA et al. 2004). In maximum parsimony (MP) analyses, heuristic searches were carried with 1000 random addition sequence replicates. Ten trees were saved at each step during stepwise addition, and tree-bisection- reconnection (TBR) was used to swap branches. Characters were unordered and equally weighted. Gaps were treated as missing data and multistate data were interpreted as uncertainty. To evaluate clade support, bootstrap values were calculated from 1000 replicates (FELSENSTEIN, 1985). Ten trees were held at each step during stepwise addition for bootstrap. Bayesian tree was used by the 4 by 4 model for base substitution and GTR + G model for optimality criterion. Bayesian inference was estimated by running 4 simultaneous chains (Metropolis Coupling Markov Chain Monte Carlo) for 1000000 generations. One tree was sampled for every ten generations. The first 2000 trees (burn in samples) were discarded, and the remaining samples were used to construct the majority-rule consensus tree. When outgroups were 
based on Leptochloa viscida and Eragrostis parviflora, the phylogenetic trees from all individuals were established by heuristic search and Bayesian inference method. Their genetic differences were analyzed by the bootstrap support (BV) and the Bayesian posterior probabilities (PP) of each branch were obtained from a repetition of 1000 times.

\section{RESULTS}

Comparing the results of maximum parsimonious and Bayesian methods, we found that phylogenetic relationship trees of sequences were so closely congruent (Figure 2). There are only two

$$
\text { SU, X. et al. }
$$

clades for previously six species of Orinus from 572 individuals (73 populations) in the phylogenetic tree. The first clade (A), tentatively named $O$. anomala Keng ex Keng f. and L. Liou, was composed of all individuals from previously Orinus alticulmus, O. anomala and O. kokonorica with BV and PP values of $100 \%$ and $95 \%$, respectively. The second clade (B), tentatively named $O$. thoroldii (Stapfex Hemsl.) Bor, consisted of previously $O$. longiglumis, O. thoroldii and O. tibeticus with $\mathrm{BV}$ and PP values of $100 \%$ and $98 \%$ respectively. In detail, there was a sister-group relationship between two clades, which all belonged to subgroups of Orinus.

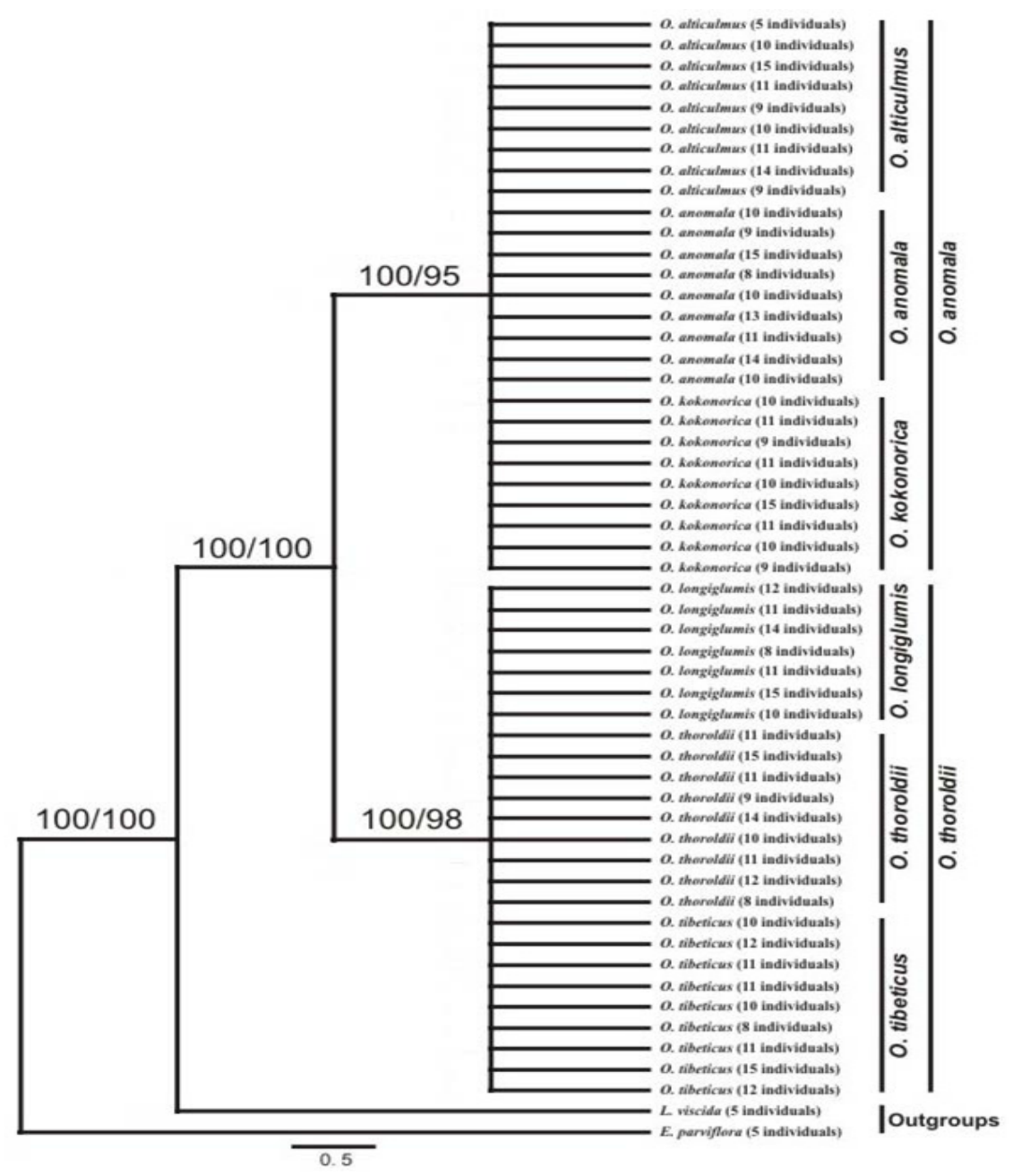

Figure 2. The maximum parsimonious tree and fifty percent of Bayesian majority rule consensus tree based on ITS sequences. Numbers above the branches indicate bootstrap support and the Bayesian posterior probabilities respectively.

\section{DISCUSSION}

Although previously six species within Orinus currently recognized by Su and Cai (2009) had a sound basis of morphology, molecular evidences have been challenging the classification. Our study revealed that $O$. longiglumis, $O$. thoroldii and $O$. tibeticus should belong to the same species, $O$. thoroldii. Similarly, Orinus alticulmus, $O$. anomala and $O$. kokonorica should be classified as 
the same species, $O$. anomala, and the two formers could be considered as a synonymy of $O$. anomala. The ITS data suggest that the classification of previously six species within the genus Orinus should be reconsidered.

Furthermore, we found that the ITS data of three species (i.e., O. alticulmus, O. anomala and $O$. kokonorica) were completely identical in A branch. Likewise, $O$. longiglumis, $O$. thoroldii and $O$. tibeticus were also exactly accordant in B branch. In addition, sixteen stable mutant differences of ITS data existed between two branches. In the previous classified research (KENG et al. 1959; LU et al. 1999; CHEN et al. 2006; SU et al. 2009), panicle morphology, spikelet length, floret number, relative length and indumentum of lemma and palea were all regarded as the classified standard among six species. Indeed, there were considerable variations from the above characters even in a population during our field investigation. Thus, the primary delimitation of DNA barcoding indicated that six species based on classical taxonomy may be divided into two species and the differences between two species were not the above morphological characters listed. During the field observation, hair numbers and growing style of lemma, glume, leaf and sheath could divide the six species into two species (The identification of two species is shown in the key), which was consistent with molecular data. This finding also needs to be validated in a population level by many morphological characters, which were the variation among species or populations and finally the marks of morphological characters under the two hereditary branches (RIESERBERG et al. 2006). An interesting phenomenon is that the partial populations from the north and west of Sichuan and east of Xizang may lie among $O$. anomala, $O$. thoroldii and $O$. tibeticus in morphology. We thus hypothesized that they should be filial generation of two hereditary branches (i.e. it may be hybrid belt and also form a single species) or an unnamed new species from one branch.

\section{Key to the species of Orinus}

1. Lemmas densely villous all over; glumes sparsely pilose; leaf blades and sheaths densely villous throughout; spikelets dark brown or purplish brown........................... Orinus thoroldii

1. Lemmas sparsely pilose or pubescent only along margins and lower keel; glumes glabrous; leaf blades and sheaths glabrous; spikelets stramineous, greenish or whitish....................... Orinus anomala

Since Orinus has a serial of unsolved questions and may be a typical model genus to study the delimitation and speciation on the QinghaiTibetan Plateau. Our further work will thus focus on: 1) counting and analyzing the variations of morphological characters of populations, testing if there is any discontinuity among their six named species, and further examining the morphological characters of Orinus populations distributing in the north and west of Sichuan and east of Xizang, to establish their systematic position; 2) investigating other micro-morphological characters, such as leaf epidermis (stomata and epidermal cells) and chromosomes (number, karyotype, etc.) and analyzing the correlation between macromorphological characters and micro-morphological characters in order to establish the circumscription of Orinus; 3) employing sequences of other genes, such as the single-copy chloroplast gene matK, $p s b \mathrm{~A}$, etc; and then comparing the results of the molecular phylogenetic analyses with the available morphological evidences; and 4) discussing the speciation history within this genus through population genetics data (i.e. SSR).

\section{Taxonomic treatment}

\section{Orinus thoroldii (Stapf ex Hemsley) Bor,} Kew Bull. 1951: 454. 1952.

Orinus thoroldii Keng in Fl. III. Pl. Prim. Sin. Gram. 284. p. 229. 1959; Bor in Grass. Burm. Ceyl. Ind. Pak. 519. 1960; Anonymous, in Icon. Cormoph. Sin. 5: 134. p. 7097. 1976; L. Liou in C. Y. Wu (ed.), Fl. Xizang. 5: 71. p. 36. 1987; X. L. Yang in Fl. Reip. Pop. Sin. 10(1): 40. 1990.

Diplachne thoroldii Stapf ex Hemsl. in J. Linn. Soc. Bot. 30: 121. 1894. Cleistogenes thoroldii (Stapf ex Hemsley) Roshevitz. Kengia thoroldii (Stapf ex Hemsley) H. Yu \& N. X. Zhao. Orinus arenicola Hitchc. in J. Wash. Acad. Sci. 23: 136. 1933. TYPE: China. Xizang (HNWP, PE).

Orinus tibeticus N. X. Zhao in Acta Bot. Yunnan. 16(3): 228. 1994, syn. nov. TYPE: China. Xizang: Dingjie County, alt. 4400 m, 1960-07-16, G. X. Fu \& J. W. Zhang 0107B (holotype, PE; isotype, $\mathrm{SCBI})$.

Orinus longiglumis X. Su \& L. B. Cai in Ann. Bot. Fenn. 46(1): 143. 2009, syn. nov. TYPE: China. Xizang: Naidong County, Jieba, $29^{\circ} 15^{\prime} \mathrm{N}$, $91^{\circ} 43^{\prime} \mathrm{E}$, alt. $3500 \mathrm{~m}, 2005-07-28$, L. B. Cai \& C. R. Luosang 002 (holotype \& isotype, HNWP); Naidong County, Zedang, 1997-10-10, P. C. Кио \& W. Y. Wang 22297 (paratype, HNWP); 1975-07-15, C. Y. Wu et al. 75-762 (paratype, HNWP \& KUN); Jiacha County, 1985-07-29, C. T. Ni \& B. D. Thaxi. 362 (paratype, XZ); Lang County, Xiaobailu, $29^{\circ} 06^{\prime} \mathrm{N}, 91^{\circ} 12^{\prime} \mathrm{E}$, alt. $3050 \mathrm{~m}, 1972-08-17$, Xizang Medic. Pl. Exped. 4415 (paratype, HNWP \& PE); 
Bange County, 1978-07-21, Suol. Sangjie 0207 (paratype, XZDC).

China. Qinghai, Xinjiang, Xizang. High arid sand, sandy wasteland or gravelly steppe, sometimes with Artemisia, fixed sand dunes; 3000$4700 \mathrm{~m}$.

China. Qinghai: Chengduo County, $X . J$. Gou \& Y. Y. Liu 83-440 (HNWP), Y. C. Yang 723 (HNWP); Datong County, Z. H. Zhang et al. 4686 (HNWP); Dulan County, Qinghai-Gansu Exped. 1392 (HNWP); Gangcha County, Vegetation Geography Group 1204 (HNWP), S. X. Wang 101 (HNWP); Gonghe County, Vegetation Geography Group 644, 1214 (HNWP), P. C. Кио 6086, 27803 (HNWP), Longyangxia Exped 107 (HNWP), H. B. G. 1524 (HNWP); Guide County, T. N. Ho 1016 (HNWP); Guinan County, B. W. Li \& K. Z. Zhang 007 (HNWP); Haiyan County, G. C. Chen 005 (HNWP); Nangqian County, People's Government of Juela Xiang, Back Mts., alt. $4100 \mathrm{~m}$, Y. C. Yang 01357 (HNWP); Qilian County, Z. Y. Qin 1370 (HNWP), South Mountain, alt. 3400 m, 1975-09-10, P. C. Kuo \& W. Y. Wang 12561 (PE); Tongde County, Y. H. Wu et al. 6773, 6814, 7208, 7267 (HNWP); Tongren County, S. W. Liu \& D. S. Luo 1164 (HNWP); Xinghai County, P. С. Кио 6100 (HNWP), T. N. Ho 0330, 0483 (HNWP), Anonymous 243 (HNWP); Xining City, Z. H. Zhang et al. 3104, 3105, 3106, 3107, 3178 (HNWP), Y. H. Wu 1866 (HNWP); Yushu County, Z. D. Wei 21854 (HNWP), Anonymous 0445 (HNWP); Zaduo County, S. W. Liu 0475 (HNWP), Anonymous 0723 (HNWP); Zeku County, S. W. Liu 1769 (HNWP). Xizang: Bomi County, alt. 4600 m, 1966-06-03, Y. T. Zhang \& K. Y. Lang s. n (PE); Changdu County, agricultural experiment field, 1954-07, Changdu farm 7 (PE); Cuoqin County, alt. 4350 m, 1974-0726, Qinghai-Xizang Exped. 1964 (PE), North East City, near Telilangmu Lake, alt. 4600 m, 1976-0915, K. Y. Lang 10299 (PE); C. Y. Wu et al. 711 (HNWP); Dangxiong County, near Yangbajin hot spring, alt. 4300 m, 1975-9-21, Xizang Exped. 7560 (HNWP, PE), Yangbajin, alt. 4100 m, 1985-08-18, J. H. Tong 1-125 (PE), Yangbajin, northwest road side, alt. 4650 m, 1960-07-14, G. X. Fu 311 (PE), Baling Town, Tangmagang, alt. $4780 \mathrm{~m}, 1985-08-$ 11, D. X. Su 022 (PE), 1985-09-09, J. H. Tong 138A (PE); Dingjie County, Kangpa Southwest, alt. 4500 m, 1961-07-13, Xizang Exped. 1614 (PE), on the way from Jinlong to Duozha, alt. $4650 \mathrm{~m}, 1960-07-$ 15, G. X. Fu \& J. W. Zhang 1011 (PE), on the way from Duozha to Dingjie County, alt. 4400 m, 196007-16, G. X. Fu 1017 (PE), 1952-08-12, B. Q. Zhong 7398 (PE), Kangpa, Zongxiadanggeliushang, 1953-08-14, B. Q. Zhong 6110 (PE), Kangpa, 1953-
08-12, B. Q. Zhong 7398, alt. 4210 m, 1975-06-17, Qinghai-Xizang Exped. 3986 (PE); Dingri County, encampment, alt. $4600 \mathrm{~m}, 1990-06-16$, ChineseJapanese Exped. T604, T606 (PE), 1990-06-17, Chinese-Japanese Exped. T638, T640 (PE), 199006-23, Chinese-Japanese Exped. T871 (PE); Gaize County, alt. 4500 m, 1972-08, F. Z. Li 018 (PE), near Uma District, alt. 4500 m, 1976-09-07, Qinghai-Xizang 12478 (PE), Zhari Namco, alt. 4600 m, 1976-09-15, Qinghai-Xizang 12578 (PE); Gaize County, near the county, alt. 4400 m, 1974-09-06, Xizang Exped. 4307 (HNWP), near the beach of Mami District, alt. 4500 m, 1976-09-07, K. Y. Lang 10142 (HNWP), northeast stone hillside of Cantor District, alt. 4600 m, 1976-09-11, K. Y. Lang 10225 (HNWP); Ge'er County, near Mentu District, alt. 4400 m, 1976-07-09, Qinghai-Xizang Exped. 767964 (PE), near Mentu District, alt. 4530 m, 197607-09, Qinghai-Xizang Exped. 13208 (PE); Geji County, near Yanhu District, alt. 4350-4450 m, 1976-08-24, Qinghai-Xizang Exped. 13535 (PE); Gonggar County, alt. $4510 \mathrm{~m}, 1975-07-07$, C. Y. Wu, S. K. Chen, Q. Du \& S. L. Lu 75-0711 (PE); Jilong County, $14 \mathrm{~km}$ west of Changguo, alt. 4650 m, 1975-07-21, Qinghai-Xizang Exped. 5437 (PE), near Jilong County, alt. 4100-4300 m, 1975-07-28, Qinghai-Xizang Exped. 5606 (PE), alt. 4400-4500 m, 1990-09-24, B. S. Li, H. Li \& Y. Yang 13964, $13965 B$ (PE); Kangma County, Gala Lake basin, alt. 4400 m, 1961-07-06, Xizang Exped. 1577 (PE); Lang County, the white village road, alt. $3050 \mathrm{~m}$, 1972-08-17, Xizang Med. Pl. Exped. 4415 (PE); Lasa City, alt. 3700 m, 1977-07-25, P. C. Kuo \& W. $Y$. Wang 22057 (HNWP), Three back mountain, alt. $3750 \mathrm{~m}, 1975-05-21,75-41$ (PE), North mountain, alt. 4100 m, 1972-10-06, Xizang Med. Pl. Exped 2061 (PE), Western suburb, alt. 3700 m, 1970-0916, P. C. Кио 8116 (PE); Lazi County, Phuntsholing, Western hill, 1952-08-23, B. $Q$. Zhong 7414 (PE), on the way from Jiadeng to Phuntsholing, 1952-08-23, B. Q. Zhong 7411 (PE), western slope of Jiaqingze, 1952-06-14, B. $Q$. Zhong 7279 (PE); Longzi County, alt. $4000 \mathrm{~m}$, 1974-08-04, Qinghai-Xizang Exped. 906, 2231 (PE); Naidong County, Zedang hostel, alt. $3650 \mathrm{~m}$, 1975-07-15, C. Y. Wu, S. K. Chen, Q. Du \& S. L. Lu 75-0762 (PE); Pulan County, near Mapam Yumco, alt. 4530 m, 1974-08-23, Inst. Biol. Xizang Exped. 4146 (HNWP); Rikaze City, Northeast, alt. 4000 m, 1972-07-26, Xizang Med. Pl. Exped. 795 (HNWP, PE), Dazhu card, alt. 3700 m, 1963-08-25, J. X. Yang 2284 (HNWP, WUK), near Yarlung Zangbo, alt. $3860 \mathrm{~m}, 1975-07-30,75-865$ (PE), Northeast, alt. 4000 m, 1972-07-26, Xizang Med. Pl. Exped. 795 (PE), $2 \mathrm{~km}$ west from the Wild Horse Gang 
Tractor farm, alt. $3800 \mathrm{~m}, 1961-07-17, J . W$. Zhang 2633 (PE); Ritu County, Duoma Town, alt. 4500 m, 1987-09-04, Qinghai-Xizang Exped. Y. H. Wu 1330 (PE, HNWP), Xiaqulong, alt. 4400 m, 1974-07-12, Xizang Exped. 3505 (HNWP), near Rebang District, alt. 4320 m, 1976-08-28, Qinghai-Xizang Exped. 76-9133 (PE); Shenzha County, near northwest corner of Qilin Lake, alt. 4650 m, 1976-09-01, Qinghai-Xizang Exped. 12414 (PE); Zhada County, Duojidong, alt. $4000 \mathrm{~m}$, 1974-08-07, Inst. Biol. Xizang Exped. 3844 (PE, HNWP), near Zhada County, alt. 4000 m, 1974-08-13, Xizang Exped. 3939 (HNWP), south and north hillside, alt. $3600 \mathrm{~m}$, 1974-07-24, Qinghai-Xizang Exped. 1904 (PE); Zhanang County, on the way from Zedang to Qushui County, alt. 3450 m, 1986-05-28, T. Naito et al. 1508 (PE), Sangyingu mountain, 1960-07, G. X. $F u 747$ (PE); Zhongba County, near Guisang, alt. 4800 m, 1975-07-24, Xizang Exped. 6450 (HNWP), alt. 4600 m, 1975-07-24, Qinghai-Xizang Exped. 5445 (PE), northeast hilly country of Guisang, alt. 4500-5000 m, 1975-07-25, Qinghai-Xizang Exped. 5508 (PE), near Zhongba County, alt. $4650 \mathrm{~m}$, 1975-08-08, Qinghai-Xizang Exped. 7234 (PE), Hongqi community, 1975-07-18, 44-7235 (PE). Xinjiang: Riqima County, alt. 4500 m, 1987-09-04, Qinghai-Xizang Exped. 1330 (PE).

$O$. tibeticus and $O$. longiglumis are two new species published on different type specimens, respectively (ZHAO et al. 1994; SU et al. 2009). However, whether the geographical distribution or external morphology, there are no any essential difference between them and the previous type species-O. thoroldii. The two new species are distributed in Xizang (Tibet) and usually occur only in high arid sand, sandy wasteland or gravelly steppe between 3040 and $4400 \mathrm{~m}$. It is slight difference of the origin of their type specimens. The type specimen of $O$. tibeticus was collected from Dingjie County of Xizang, while that of $O$. longiglumis was sampled from Naidong and Lang County of Xizang. Moreover, the altitude of the former $(4400 \mathrm{~m})$ is higher than that of the latter (3040-3650 m). They are known only from several small localities in Xizang. In contrast, O. thoroldii has a wide distribution, occurring throughout the QTP (CAI et al. 2004). So its distribution regions cover that of these two new species, and the habitat is very similar with $O$. tibeticus and $O$. longiglumis. It usually grows in high arid sand, sandy wasteland or gravelly steppe, fixed sand dunes of 3051-4687 m and its type specimen also originated from Xizang. In external morphology, all characters among three species belong to continuous variation. According to description of new species published, differences of type specimens between $O$. tibeticus and $O$. thoroldii only are that culms of $O$. tibeticus are covered with densely villous or pilose, spikelets are bigger and (8-) 9-11 mm long. Actually, through herbarium specimens and field observation, we found culms of $O$. thoroldii also covered with densely villous or pilose, and most characters like longer spikelets were often met. Thus, these different characters established $O$. tibeticus should belong to transitional traits and it was difficult to species recognition using them. This indicates some difference between $O$. tibeticus and $O$. thoroldii should be the result of environmental alteration. It is not enough to constitute interspecific delimitation. Therefore, $O$. tibeticus and $O$. thoroldii should belong to the same species, and O. tibeticus should be reduced to synonym of $O$. thoroldii. Similarly, $O$. longiglumis is also similar with $O$. thoroldii, only differs by having longer panicles, glumes and anthers, and by paleas that are shorter than lemmas. Based on above differences, the author published this new species (SU et al. 2009). Just as $O$. tibeticus does, these variation characters are also not enough to become interspecific delimitation. $O$. longiglumis and $O$. thoroldii should be the same species. Namely, $O$. longiglumis should be treated as the synonym of $O$. thoroldii as well.

Orinus anomala Keng ex Keng f. et $L$. Liou in Acta Bot. Sin. 9(1): 68. 1960.

Orinus anomala X. L. Yang in Fl. Reip. Pop. Sin. 10(1): 41. 1990; S. L. Chen \& S. M. Phillips in C. Y. Wu (ed), Fl. China 22: 465. 2006, syn. nov. TYPE: China. Sichuan: G. L. Qu 7469 (HNWP, PE).

Orinus kokonorica Keng in Icon. Cormoph. Sin. 5: 133. p. 7096. 1976; S. L. Chen \& S. M. Phillips in C. Y. Wu (ed), Fl. China 22: 464. 2006. Cleistogenes kokonorica K. S. Hao in Bot. Jahrb. Syst. 68: 582. 1938. D-Diplachne kokonorica (K. S. Hao) Conert. K-Kengia kokonorica (K. S. Hao) Packer, syn. nov. TYPE: China. Qinghai: Gonghe county, Qieji Xiang (HNWP).

Orinus alticulmus L. B. Cai \& T. L. Zhang in Novon 18: 275. 2008, syn. nov. TYPE: China. Qinghai: Xining City, Yangjiazhai, near Xining Botanical Garden, alt. $36^{\circ} 36^{\prime} \mathrm{N}, 101^{\circ} 48^{\prime} \mathrm{E}, 2450 \mathrm{~m}$, 1985-08-14, Y. H. Wu 1913 (halotype, HNWP; isotype, PE); Xining City, Xi Mtns., Xishanlinchang, alt. 2500 m, 1985-08-13, Veget. Geogr. Exped. 889 (paratype, HNWP); 2005-08-02, L. B. Cai \& B. H. Ma 001 (paratype, HNWP); Gonghe County, Longyangxia, 2600 m, 1983-08-17, Longyangxia Exped. 002, 019 (paratype, HNWP). 
China. Qinghai, Sichuan, Gansu. Dry mountain slopes, steppe; 2400-4200 m.

China. Qinghai: Chengduo County, Labu commune, Xieqionglong, alt. 3900 m, 1983-09-11, Y. Y. Liu 83-440 (HNWP); Datong County, Baoku, alt. $2700 \mathrm{~m}, 1989-07-27$, Z. H. Zhang et al. 4686 (HNWP); Gangcha County, Ji Er Men Xiang, alt. $3380 \mathrm{~m}$, S. X. Wang 101 (HNWP), Bird Island Station, alt. $3350 \mathrm{~m}$, 1988-08-26, Vegetation Geography Group 1214 (HNWP); Gonghe County, P. C. Кио \& S. X. Wang 6476, 6486 (HNWP), K. Z. Zhang 631016 (HNWP); Gonghe County, Longyangxia, North shore canyon, alt. $2700 \mathrm{~m}$, 1987-08-19, Longyangxia Exped 107 (HNWP), Jiayi Xiang, SE shore of Kolo Nor (Qinghai Lake), $36^{\circ} 35^{\prime} 15^{\prime \prime} \mathrm{N}, 100^{\circ} 29^{\prime} 26^{\prime \prime} \mathrm{E}$, alt. $3440 \mathrm{~m}, 1993-08-$ 21, T. N. Ho 1524 (HNWP, PE), Yitala, alt. $3000 \mathrm{~m}$, 1965-07-15, P. C. Кио 6086 (HNWP), Heka, Karihong mountain, alt. $3200 \mathrm{~m}, 1965-07-17, P$. C. Kuo 6100 (HNWP), near Qinghai Lake, alt. 3500 m, 1985-07, P. C. Кио 27803 (HNWP); Guinan County, Hanmachang, alt. 3100 m, 1967-07-22, B. W. Li \& K. Z. Zhang 007 (HNWP); Haiyan County, Vegetation Geography Group 1264, 1301 (HNWP), G. C. Chen \& S. Z. Sun 686 (HNWP); Henan County, L. H. Zhou \& L. N. Sun 2287 (HNWP); Nangqian County, People's Government of Juela Xiang, alt. 4100 m, 1965-08-25, Y. C. Yang 01357 (HNWP); Nangqian County, along west side of the Zaqu (upper Mekong), on road between Nangqian and Yushu County, $32^{\circ} 17^{\prime} \mathrm{N}, 96^{\circ} 28^{\prime} \mathrm{E}$, alt. $3550 \mathrm{~m}$, 1996-09-01, T. N. Ho, B. Bartholomew, M. Watson \& M. Gilbert 2759 (PE); Qilian County, Dove hole, 1962-07-21, Z. Y. Qin 003613 (HNWK), 1390 (HNWK, WUK); Tongde County, near hillside in grassland station, 1990-08-22, Y. H. Wu et al. 7267 (HNWP); Wulan County, Chaka, alt. 3200 m, 195908-12, Qinghai-Gansu Exped. 1392 (HNWK, WUK, PE), Chaka, alt. 3100 m, 1959-08-12, Qinghai-Gansu Exped. Z. Y. Zhang 1359 (WUK, PE); Xining City, Xining Botanical Garden, North mountain, alt. $2600 \mathrm{~m}$, 1985-08-05, Y. H. Wu 1866 (HNWP), Dayou mountain, alt. 2320 m, 1989-0718, Z. H. Zhang et al. 3104 (HNWP), Xichuanxixing Garden, alt. 2455 m, 1989-07-16, Z. H. Zhang et al. 3105, 3106, 3178 (HNWP), Xichuanxixing Garden, alt. 2498 m, 1989-07-16, Z. H. Zhang et al. 3107 (HNWP); Xinghai County, Tangnai River, alt. 2800 m, Anonymous 243 (HNWP), Heka town, Ningqu mountain, alt. 3600 m, 1965-08-17, T. N. Ho 00483 (HNWP), Heka town, Yangqu, alt. $3500 \mathrm{~m}, 2001-08-25, Y . H . W u$ 20357, 20425, 20429, 20438, 20491 (HNWP), Heka beach, alt. $3270 \mathrm{~m}, 1983-07-05$, Z. W. Zhang 2080 (WUK); Tiebujia, alt. 3325 m, 1961-08-04, 010
(PE); Zaduo County, near Angsai Government, alt. 3850 m, 1965-08-21, S. W. Liu 00475 (HNWP); Zeku County, Ningxiu Xiang, Ningxiu beach, alt. 3500 m, 1970-09-11, S. W. Liu 1769 (HNWP). Xizang: Bomi County, alt. 2700 m, 1973-07-02, Inst. Biol. Xizang Exped. 0787 (PE); Lasa City, North mountain, alt. 4100 m, 1972-10-06, Xizang Med. Pl. Exped 2061 (PE); Linzhi County, 1977-0725, P. C. Кио \& W. Y. Wang 21917 (HNWP). Gansu: Sunan County, Haiya distch, alt. $2750 \mathrm{~m}$, 1960-07-14, Z. Y. Zhang 3284 (WUK), Dahe District, Beiquanmen distch, alt. 2900 m, 1967-0825, Hexi Exped. 476 (PE), Laihaiyajing, alt. $2750 \mathrm{~m}$, 1960-07-14, Qinghai-Gansu Exped. 3284 (PE), Wuwei, Xiying river, forest farm, alt. 2500 m, 196410-04, 2077 (PE). Sichuan: Aba County, 1974-0716, Anonymous 05585 (PE); Dege, $3 \mathrm{~km}$ north of Manigange, alt. 3900 m, 1982-08-06, Z. X. Tang, X. W. Tian \& Q. G. Sun 657 (PE); Dengke County, alt. 3400 m, 1974-08-22, Anonymous 7654 (PE); Ganzi County, Rongpen temple, alt. 3570 m, 1982-08-31, Z. X. Tang 0872 (PE); Luhuo County, Qiaqia, alt. 3480 m, 1980-08-24, Anonymous 28515 (HNWP); Songpan County, Chimney, alt. 3100 m, 1983-0802, Z. X. Tang 1598 (PE); Wenchuan County, Kezhi Xiang, north Tieling Group, alt. 1500 m, 1983-0903, 1928 (PE).

Previous scholars thought that difference between new species, $O$. anomala, and its related taxa, O. kokonorica, was lemmas of the latter were covered with sparsely pilose or pubescent (TZVELEV, 1968; YANG, 1990; LU, 1999; CHEN et al. 2006). However, this viewpoint was originally opposed by Cai (2004). Nowadays, by further morphological comparsion and field observation, we found that interspecific difference between $O$. kokonorica and $O$. anomala was inconspicuous. Namely, in the past, character differences of spikelets, florets, glumes and lemmas were pointed out, which has become this fact that there are significant overlap in length of spikelets and glumes, and number of florets. Besides, there is transition in lemmas with sparsely pilose or pubescent. It is clear that above taxonomic differences reused by previous scholars are unstable. So previous recognized species, $O$. anomala, should not be untenable. It is very probably synonym of the same species. Like as $O$. anomala, $O$. alticulmus differed from $O$. kokonorica in shape of panicles and number of florets (ZHANG et al. 2008). $O$. alticulmus owns slightly effuse panicles, longer spikelets $(8-10 \mathrm{~mm})$ usually with 3 florets, and paleas usually longer than lemmas. Especially, $O$. alticulmus differs from $O$. kokonorica by its taller culms (usually $40-75 \mathrm{~cm}$ ). Nevertheless, we found 
that above external morphological characters could not distinguish these two species. It is because that recognized characters with $O$. alticulmus do not exceed variation range of morphological characters of $O$. kokonorica. For example, culm height of most $O$. kokonorica exceeds $40 \mathrm{~cm}$, some of them are up to $84.7 \mathrm{~cm}$; length of most spikelets is between 5.2 to $14.5 \mathrm{~mm}$, with 1-3 florets. Thus, there are many overlapping characters between $O$. kokonorica and O. alticulmus. Based on specimens of O. alticulmus, many morphological characters are also not consistent with original description of new species reported. For instance, culm height of $O$. alticulmus is between 19.1 and $76.0 \mathrm{~cm}$; spikelet length ranges from 3.5 to $10.2 \mathrm{~mm}$, with 1-3 florets. We think that it may be related to number, region and habitat of tested specimens. Merely, all variation characters of $O$. alticulmus should belong to variation range of external morphology of $O$. kokonorica. So in view of them, this study specially makes $O$. anomala and $O$. alticulmus treat as synonyms of $O$. kokonorica.

\section{ACKNOWLEDGEMENTS}

We gratefully acknowledge Dr. Xuhui Zhou for revising this paper. This research was supported by the National Science Foundation of China (31260052), the Natural Science Foundation of Qinghai Province (2014-ZJ-947Q), the Key Laboratory of Medicinal Animal and Plant Resource in the Qinghai-Tibetan Plateau (2015-Z-Y06), the State Key Laboratory Breeding Base-Key Laboratory of Qinghai Province for Plateau Crop Germplasm Innovation and Utilization (2013-01), and the Young and Middle-Aged Research Foundation of Qinghai Normal University (201519).

RESUMO: Neste estudo, sequências ITS do DNA ribossômico nuclear foram conduzidas para seis espécies putativas de Orinus (O. alticulmus, O. anomala, O. kokonorica, O. longiglumis, O. thoroldii and O. tibeticus) com 572 indivíduos de 73 populações. Os resultados revelaram que as seis espécies formaram dois grupos monofiléticos: o primeiro (O. anomala Keng ex Keng f. and L. Liou) com O. alticulmus, O. anomala and O. kokonorica, e o segundo (O. thoroldii (Stapfex Hemsl.) Bor) com O. longiglumis, O. thoroldii and O. tibeticus. Os dados taxonômicos das sequências ITS não foram congruentes com aqueles das características morfológicas, provavelmente resultantes da rápida especiação provocada pelas elevações do Planalto do Tibete e das suas regiões adjacentes e da grande pressão de seleção nos ambientes alpinos. Os dados ITS sugerem que a classificação das seis espécies dentro do gênero Orinus deveriam ser reduzidas para duas espécies. Nós incluímos uma revisão taxonômica completa do gênero e uma chave para distinguir as duas espécies. Portanto, é absolutamente necessário fazer uma revisão abrangente e um arranjo destes táxons, regular estritamente a confusão de táxons de gêneros e ordem de espécies, e fazer novos relatórios sobre pertencer aos táxons de gêneros.

PALAVRAS-CHAVE: Planalto do Tibete. Orinus. Circunscrição. Filogenia.

\section{REFERENCES}

BALDWIN, B. G. Phylogenetic utility of the internal transcribed spacers of nuclear ribosomal DNA in plants: an example from the compositae. Molecular Phylogenetics and Evolution, v. 1, n. 1, p. 3-16, 1992. http://dx.doi.org/10.1016/1055-7903(92)90030-K

BALDWIN, B. G. Molecular phylogenetics of Calycadenia (Compositae) based on ITS sequences of nuclear ribosomal DNA: chromosomal and morphological evolution reexamined. American Journal of Botany, v. 80, p. 222-238, 1993. http://dx.doi.org/10.2307/2445043

BALDWIN, B. G.; SANDERSON, M. J.; PORTER, J. M.; WOJCIECHOWSKI, M. F.; CAMPBELL, C. S.; DONOGHUE, M. J. The ITS region of nuclear ribosomal DNA: a valuable source of evidence on angiosperm phylogeny. Annals of the Missouri Botanical Garden, v. 82, p. 247-277, 1995.

http://dx.doi.org/10.2307/2399880

BOR, N. L. The genus Orinus Hitchcock. Kew Bulletin, v. 6, n. 3, p. 453-455, 1952. http://dx.doi.org/10.2307/4118026

BOR, N. L. Grasses of Burma, Ceylon, India and Pakistan. Pergamon Press, Oxford, p. 519, 1960. 
CAI, L.; ZHANG, Y.; ZHANG, T. Relationships among genera of Tridentinae from China based on some leaf epidermal characteristics. Acta Bot. Boreali-Occidentalia Sin, v. 24, n. 9, p. 1691-1696, 2004.

CHEN, S.; PHILLIPS, S. M. Orinus. p. 464-465 in WU, C.; RAVEN, P. H.; HONG, D. (editors), Flora of China, Vol. 22. Science Press, Beijing, and Missouri Botanical Garden Press, St. Louis, 2006.

DOYLE, J. J.; DOYLE, J. L. A rapid DNA isolation procedure for small quantities of fresh leaf material. Phytochemical Bulletin, v. 19, p. 11-15, 1987.

FELSENSTEIN, J. Confidence limits on phylogenies: an approach using the bootstrap. Evolution, v. 39, n. 4, p. 783-791, 1985. http://dx.doi.org/10.2307/2408678

GAO, L.; LI, D.; ZHANG, C. Phylogenetic relationships of Rhododendron section Azaleastrum (Ericaceae) based on ITS sequences. Acta Phytotaxonomica Sinica, v. 41, n. 2, p. 173-179, 2003.

KENG, P.; LIOU, L. A study on the tribe Eragrostideae and its two genera new to China. Chinese Bulletin of Botany, v. 9, n. 1, p. 48-75, 1960.

HITCHCOCK, A. S. New grasses from Kashmir. Journal of Washington Academy of Sciences, v. 23, p. 134136, 1933.

HUELSENBECK, J. P.; RONQUIST, F. MrBayes: Bayesian inference of phylogeny. Bioinformatics, v. 17, p. 754-755, 2001. http://dx.doi.org/10.1093/bioinformatics/17.8.754

KENG, Y. Orinus Hitchcock. In: Claves Generum et Specierum Graminearum Primarum Sinicarum Appendice Nomenclatione Systematica, Eds: KENG, Y. Science Press, Beijing, p. 58, 1957.

KENG, Y. Orinus Hitchcock. In: Flora Illustralis Plantarum Primarum Sinicarum Gramineae, Eds: KENG Y. Science Press, Beijing, p. 283-286, 1959.

KENG, P.; LIOU, L. A study on the tribe Eragrostideae and its two genrera new to China. Acta Botanica Sinica, v. 9, n. 1, p. 48-75, 1960.

LI, D.; GAO, L.; LI, H.; WANG, H.; GE, X.; LIU, J.; CHEN, Z.; ZHOU, S.; CHEN, S.; YANG, J.; FU, C.; ZENG, C.; HE, X.; KONG, H.; ZHANG, L.; YAN, H.; ZHU, Y.; SUN, Y.; CHEN, S.; ZHAO, L.; SONG, J.; WANG, Q.; LU, L.; WANG, R.; WU, D.; HANG, Y.; CI, X.; ZHANG, J.; ZHANG, S.; REN, B.; SHUI, Y.; WANG, K.; YANG, T.; DUAN, G.; LIU, J.; YU, W.; ZHANG, D.; YANG, Q.; MENG, Y.; ZHANG, C.; HUANG, L.; JI, Y.; JIN, X.; ZHOU, Y.; LI, H.; PAN, Y.; SONG, C.; DONG, X.; YI, T.; HAO, G.; ZHOU, S.; XUE, C.; XIAO, P.; LIU, Z.; SUN, Y.; CHEN, L.; ZHANG, Y.; HUANG, Y.; XIANG, C.; QI, Z.; WANG, Y.; YANG, $X$. Comparative analysis of a large dataset indicates that internal transcribed spacer (ITS) should be incorporated into the core barcode for seed plants. Proceedings of the National Academy of Sciences of the United States of America, v. 108, n. 49, p. 19641-19646, 2011a. http://dx.doi.org/10.1073/pnas.1104551108

LI, D.; LIU, J.; CHEN, Z.; WANG, H.; GE, X.; ZHOU, S.; GAO, L.; FU, C.; Chen, S. Plant DNA barcoding in China. Journal of Systematics and Evolution, v. 49, n. 3, p. 165-283, 2011b. http://dx.doi.org/10.1111/j.17596831.2011.00137.x

LIU, J.; WANG, Y.; WANG, A.; HIDEAKI, O.; ABBOTT, R. J. Radiation and diversification within the Ligularia-Cremanthodium-Parasenecio complex (Asteraceae) triggered by uplift of the Qinghai-Tibetan Plateau. Molecular Phylogenetics and Evolution, v. 38, n. 1, p. 31-49, 2006.

http://dx.doi.org/10.1016/j.ympev.2005.09.010

LU, S. Orinus Hitchcock. p. 172-173 in LIU, S. (editors), Flora Qinghaiica, Vol. 4. Qinghai People's Publishing House, Xining, 1999. 
POSADA, D.; BUCKLEY, T. R. Model selection and model averaging in phylogenetics: advantages of Akaike information criterion and bayesian approaches over likelihood ratio tests. Systematic Biology, v. 53, n. 5, p. 793-808, 2004. http://dx.doi.org/10.1080/10635150490522304

POSADA, D.; CRANDALL, K. A. MODELTEST: testing the model of DNA substitution. Bioinformatics, v. 14, n. 9, p. 817-818, 1998. http://dx.doi.org/10.1093/bioinformatics/14.9.817

RIESEBERG, L. H.; WOOD, T. E; BAACK, E. J. The nature of plant species. Nature, v. 440, p. 524-527, 2006. http://dx.doi.org/10.1038/nature04402

STAPF, O. On two small collections of dried plants from Tibet. In: Eds: HEMSLEY, W. B.; STRACHEY, R. Botanical Journal of the Linnean Society, v. 30, n. 206, p. 121, 1894.

SOLTIS, D. E.; SOLTIS, P. S. Choosing an approach and an appropriate gene for phylogenetic analysis. In: Molecular Systematics of Plants. II. DNA Sequencing, Eds: SOLTIS, D. E.; SOLTIS, P. S.; DOYLE, I. I. Kluwer Academic Publishers, Boston, p. 47-73, 1998. http://dx.doi.org/10.1007/978-1-4615-5419-6 http://dx.doi.org/10.1007/978-1-4615-5419-6_1

SU, X.; CAI, L. Orinus longiglumis (Poaceae: Chloridoideae), a new species from Xizang (Tibet), China. Annales Botanici Fennici, v. 46, n. 2, p. 143-147, 2009. http://dx.doi.org/10.5735/085.046.0211

SWOFFORD, D. L. PAUP*. Phylogenetic analysis using parsimony (and other methods) (version 4).

Sunderland, Massachusetts: Sinauer Associates, 2000.

TAMURA, K.; PETERSON, D.; PETERSON, N.; STECHER, G.; NEI, M.; KUMAR, S. MEGA5: molecular evolutionary genetics analysis using maximum likelihood, evolutionary distance, and maximum parsimony methods. Molecular Biology and Evolution, v. 28, n. 10, p. 2731-2739, 2011.

http://dx.doi.org/10.1093/molbev/msr121

THOMPSON, J. D.; GIBSON, T. J.; PLEWNIAK, F.; JEANMOUQIN, F.; HIQQINS, D. G. The Clustal_X windows interface: flexible strategies for multiple sequence alignment aided by quality analysis tools. Nucleic Acids Research, v. 25, n. 24, p. 4876-4882, 1997. http://dx.doi.org/10.1093/nar/25.24.4876

TIAN, X.; LI, D. Application of DNA sequences in plant phylogenetic study. Acta Botanica Yunnanica, v. 24, n. 2, p. 170-184, 2002.

TZVELEV, N. N. Plantae Asiae Centralis (Vol. 4). Nauka Publishers, Leningrad, p.112, 1968.

VARGAS, P.; BALDWIN, B. G.; CONSTANCE, L. Nuclear ribosomal DNA evidence for a western North American origin of Hawaiian and South American species of Sanicuta (Apiaceae). Proceedings of the National Academy of Sciences of the United States of America, v. 95, n. 1, p. 235-240, 1998. http://dx.doi.org/10.1073/pnas.95.1.235

WANG, A.; YANG, M.; LIU, L. Molecular phylogeny, recent radiation and evolution of gross morphology of the rhubarb genus Rheum (Polygonaccae) inferred from chloroplast DNA trnL-F sequences. Annals of Botany, v. 96 , n. 3, p. 481-498, 2005. http://dx.doi.org/10.1093/aob/mci201

WANG, Y.; LIU, J. A preliminary investigation on the phylogeny of Saussurea (Asteraceae: Cardueae) based on chloroplast DNA trnL-F sequences. Acta Phytotaxonomica Sinica, v. 42, n. 2, p. 136-153, 2004.

WHITE, T. J.; BRUNS, T. D.; LEE, S. B.; TAYLOR, J. W. Amplification and direct sequencing of fungal ribosomal RNA genes for phylogenetics. In: PCR protocols, Eds: INNIS, M.; GELFAND, D.; SNINSKY, J.; WHITE, T. San Diego, CA: Academic Press. p. 315-322, 1990. http://dx.doi.org/10.1016/b978-0-12-3721808.50042-1 
YANG, X. Orinus Hitchcock. p. 39-41 in CHEN, S. (editors), Flora Reipublicae Popularis Sinicae. Vol. 10. Science Press, Beijing, 1990.

ZHANG, T.; CAI, L. A New Species of Orinus (Poaceae) from Qinghai, China. Novon, v. 18, n. 2, p. 273-278, 2008.

ZHANG, Q.; CHIANG, T. Y.; GEORGE, M.; LIU, J.; ABBOTT, R. J. Phylogeography of the Qinghai-Tibetan Plateau endemic Juniperus przewalskii (Cupressaceae) inferred from chloroplast DNA sequence variation.

Molecular Ecology, v. 14, n. 11, p. 3513-3524, 2005. http://dx.doi.org/10.1111/j.1365-294X.2005.02677.x

ZHAO, N.; LI, M. New taxa and new recording species of Gramineae from Tibet. Acta Botanica Yunnanica, v. 16, n. 3, p. 228-230, 1994. 